\title{
Staropolskie struktury i satyry menippejskie. Próba typologii gatunku
}

\begin{abstract}
Kusiak Jolanta, Staropolskie struktury i satyry menippejskie. Próba typologii gatunku [Old Polish satires and menippean structures. An attempt at a typology of the genre]. ${ }_{n}$ Przestrzenie Teorii" 10. Poznań 2008, Adam Mickiewicz University Press, pp. 243-255. ISBN 978-83-2321946-0. ISSN 1644-6763.
\end{abstract}

In the article Old Polish satires and menippean structures. An attempt at a typology of the genre the author took up the subject of the possibility of existence of this kind of satire derived from the antique tradition. Thus, what needed to be more precisely explained was the incoherent theoretical classification of ancient menippean satires and their influence on the later texts. An attempt at ordering the hitherto statements on the subject by scholars (among other M. Bakhtin, N. Frye, D. Shanzer, H. Rikonnen, K. Korus, R. Piętka and J. Styka) was enriched with a not well-known German studies, especially Stefan Trappen's important book. The outline of the background of antique tradition of the genre allowed a wider view at the 17 th and 18 th century texts (old Polish texts) amongst which menippean satires can be found. On the grounds of native history of literature a division appeared to be indispensable into texts which either formally or actualiy belong to this genre, thus to the menippean structures and satires. The form of prosimetrum which characterises, among other things, Gadka Hrycia z Fortuną [Hryćs chat with Fortune] by J.S. Herburt or Something New... by $\mathrm{t}$. Opalinski does not necessarily become the only constitutive genological feature of mennipea. Tracking the presence of the menippean satire in old literature ended with the observation of 4 important works: Żona wyćwiczona [A Well-trained Wife], Złote jarzmo małżenskie [The Golden Yoke of Marriage], Gorzka wolność młodzieńska [The Bitter Freedom of Youth] and Małpa-człowiek w cnotach, obyczajach i kroju [The Monkey in virtues, customs and clothes]. The suggested inter-genre division into satires and structures allows to see the ties which join Polish literature with European traditions, and at the same time takes into account their distinctness. The standard example of this is a form of a manippean letter (among others, often found in I. Krasicki's works), noted as an aftermath of menippea. The article fits within the current of philological studies on the menippean satire, which has been undertaken only recently.

Satyrą menippejską - według przystępnej definicji - określa się „utwory satyryczne mieszające wiersz z prozą, posługujące się swobodnie rozmaitymi formami stylistycznymi i gatunkowymi wypowiedzi"1. Prawodawcą gatunku, upamiętnionym w nazwie, był grecki filozof ze szkoły cynickiej Menippos z Gadary² (1 poł. III w. p.n.e.). Początków satyry me-

1 J. Sławiński, Satyra menippejska, hasło w: Słownik terminów literackich, pod red. J. Sławińskiego, wyd. 4, Wrocław 2005, s. 498.

2 „Pochodził z najniższych warstw społeczeństwa, a dorobiwszy się w jakiś sposób majątku uzyskał obywatelstwo Teb. Tutaj albo pod wpływem Kratesa, albo jego ucznia Metroklesa został wyznawcą filozofii cynickiej” - cyt. za: M. Cytowska, H. Szelest, Literatura grecka i rzymska w zarysie, Warszawa 1981, s. 109. 
nippejskiej upatrywać można w diatrybie cynickiej, jaką niewątpliwie Menippos uprawiał. Możliwe jest jednak drugie źródło jej genezy ${ }^{3}$, o semickich korzeniach ${ }^{4}$. Wcześniej od Menipposa z Gadary formą podobną posłużyć się mogli: Antystenes z Aten, uczeń Sokratesa, Herakleides z Pontu, uczeń Platona, czy Bion Borystenita znad Dniepru ${ }^{5}$. Ocalały jedynie ślady twórczości Menipposa - w doksograficznym dziele Diogenesa Laertiosa Żywoty $i$ poglqdy stynnych filozofów - oraz wzmianki w tekstach Marka Terencjusza Warrona i Lukiana z Samosaty, w których $z$ utworów Gadareńczyka zachowały się dwa szczątki: poetycki i prozatorski oraz kilka ich tytułów: Testamenty, Rozmowy ze zmarlymi ${ }^{6}$, Sympozjon i Arkezylaos?.

Warrona (I w. p.n.e.) Saturae menippae tytułem już świadczą o protoplaście gatunku, a również tylko na podstawie ocalałych fragmentów, pisanych naprzemiennie prozą i wierszem, opisać je można jako „gawędy"8, atakujące ówczesne obyczaje oraz wysokich urzędników ${ }^{9}$. Dla Lukiana z Samosat literackim wzorcem, na który często się powoływał, był Menippos. W Dialogach grecki cynik występuje wielokrotnie jako rozmówca, zaś w Podwójnie oskarżonym został on - co cenne - scharakteryzowany jako pisarz ${ }^{10}$. Zajadłość i zjadliwość satyryczna Menipposa

${ }^{3}$ Choć ,istnieje jednak pogląd, iż prozimetrum przynależy do greckiej kultury oralnej i dopiero w III wieku przed Chr. uzyskało formę literacką" - zob.: J. Styka, Satyra menippejska Warrona: problem gatunkowej odrębości. „Meander” R. 48, 1993, z. 9-10, s. 442.

${ }^{4}$ O syryjskim i semickim rodowodzie menippei zob.: G. Highet, The Anatomy of Satire, Princeton 1962, s. 251, przyp. 23.

5 Zob.: M. Bachtin, Problemy poetyki Dostojewskiego, przeł. N. Modzelewska. Warszawa 1970, s. 173, oraz R. Piętka, Menippos i inni. O początkach satyry menippejskiej, "Meander" R. 53, 1998, z. 5, s. 439-444.

6 Warto odnotować, iż od Menipposa z Gadary wywodzą się odrębne wobec satyr rozmowy zmarłych, które spopularyzowane przez Lukiana z Samosaty uprawiali w nowożytności, np. Fontenelle czy Ignacy Krasicki. Zob.: Z. Sinko, Oświeceni wśród Pól Elizejskich. „Rozmowy zmarlych”. Recepcja - twórczość oryginalna, Wrocław 1976.

${ }^{7}$ Podaję za: R. Piętka, op. cit., s. 439.

${ }^{8}$ M. Cytowska, H. Szelest, op. cit., s. 265.

${ }^{9} \mathrm{U}$ Warrona pojawia się motyw wędrówki w zaświaty, gdzie rozmówcą jest Menippos. Dosadny język (jedna z satyr zatytułowana jest Nocnik ma swojq objętość, czyli o pijaństwie), plastyka obrazu i zjadliwa krytyka oraz duża dowolność stylu to naczelne cechy zbioru 150 satyr: zob.: R. Piętka, Satyra menippejska jako gatunek pre-powieściowy (na przyktadzie utworów Warrona i Seneki), „Meander” R. 53, 1998, z. 6, s. 603-619.

${ }^{10}$ Lukian, Podwójnie oskarżony, w: tegoż, Dialogi, t. 2, przeł. M.K. Bogucki, kom. opatrzył W. Madyda, Wrocław 1962, s. 280, „Biblioteka Przekładów z Literatury Antycznej”, t. 8: „Odjął mi ową tragiczną, stateczną, a włożył inną, komiczną, satyryczną, nieomal błazeńską maskę. Sprzęgnął mię z szyderstwem, jambem, cynizmem, z Eupolisem, $z$ Arystofanesem, $z$ tymi mistrzami $w$ drwieniu $z$ tego, co czcigodne, w nicowaniu tego, co rzetelne. Wreszcie na dobitek wykopał, wydobyl z grobu starego Psa, niejakiego Me- 
przebijały silnie $\mathrm{z}$ jego tekstów, przysporzyły mu też przydomku

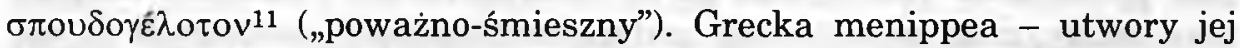
twórcy, Warrona i Lukiana - była, jak wynika z zachowanych fragmentów i tekstów, zdialogizowaną napastliwą, często personalną, krytyką rzeczywistości, obyczajów i porządków. Paralelna jej rzymska odmiana: Apocolocyntosis Divi Claudii Seneki Młodszego ${ }^{12}$, Satyryki Petroniusza ${ }^{13}$ i Metamorfozy albo złoty osioł Apulejusza ${ }^{14}$ zaskakująco odmiennie rozwinęła gatunek. Wspólny im jest element pozaziemski, nadprzyrodzony, choć niepozbawiony komizmu. Poza ocalałymi fragmentarycznie satyrami Menipposa i Warrona ich rzymskie kontynuacje genologiczne uznaje się za antyczny paradygmat satyry menippejskiej, choć greckie ich warianty są nie do przecenienia. Stąd klasyfikacja, jaką zaproponował Stefan Trappen, zdaje się uwzględniać różnorodność starożytnych tekstów:

Die sechs Autoren, denen wir die antike Entfaltung der menippeischen Satire verdanken, sind drei schreibende: Lukian von Samostata, Julianus Apostata (Caesares), Plutarch (Gryllos) und drei Lateiner: Seneca (Apocolocyntosis), Petron (Satyricon), Apuleius (Metamorphosen oder Goldener Esel) ${ }^{15}$.

Odmienność związanych jedną formą utworów kusiła do znalezienia dla nich wspólnego klucza, którym byłaby nie tylko zewnętrzna forma przeplotu prozy i poezji. Michał Bachtin, traktujący gatunkową powłokę

nipposa, niepohamowanego w szczekaniu, zajadłego, i przywiódl do mnie. Kundel to prawdziwie groźny: ani się spostrzeżesz, jak cię ukąsi, a kąsa śmiejąc się przy tym" (podkr. moje - J.K.).

${ }^{11}$ R. Piętka, op. cit., s. 605.

${ }^{12}$ Seneki Apocolocyntosis. Satyra na śmierć cesarza Klaudiusza i jego pozgonne wędrówki do nieba $i$ do podziemia, przel., rozprawą wstępną i objaśnieniami opatrzył L. Ćwikliński, Poznań 1926, s. 17-18: „Jest zatem pisemko Seneki jednym z niewielu zabytków satyry menippejskiej, satyry prozaicznej, wierszami przetykanej. [...] Wzorem głównym był jednak dla Seneki, i to zarówno pod względem formy, jak treści, wspomniany Menippos [...]. Seneka posługuje się wielu z Menippa zapożyczonemi motywami, korzysta $\mathrm{z}$ tego wzoru, kiedy opisuje pobyt Klaudiusza w niebie i pełne obrady bogów, a nie mniej kiedy czytelnikowi uprzytomnia scenę sądową w Hadesie. Grecki satyryk dostarczył mu również różnych zwrotów, z jego utworów wziął nawet różne drobne szczegóły".

${ }^{13}$ Petroniusz, Satyryki, przeł. i oprac. M. Brożek, BN II 154, Wrocław 1986, s. 47: „przyjąć należy raczej bezpośredni formalny wpływ satyry menippejskiej na wybór formy w utworze [romansie] Petroniusza".

${ }^{14}$ Apulejusz, Metamorfozy albo ztoty osioł, przeł. E. Jędrkiewicz, przypisy w oprac. T. Sinki, wyd. 3, Warszawa 1976.

15 S. Trappen, Grimmelshausen und die menippeische Satire. Eine Studie zu den historischen Voraussetzungen der Prosasatire im Barock, Tübingen 1994, s. 139 (Landesbibliothek Stuttgart, 44/1105). 
jako pretekst do rozciągania go na heterogeniczne i czasowo odrębne inne teksty, znak wywoławczy "satyra menippejska” zastosował do np. Dostojewskiego. Przedstawił jednak podstawowe właściwości tego gatunku w postaci, jaka ukształtowała się w starożytnosci16. Uzupełnienie listy przyniosła rozprawa Menippean Satire as Literary Genre with Special Reference to Seneca's Apocolocyntosis Hansa K. Riikonena ${ }^{17}$. Fiński

${ }^{16}$ M. B a c h t i n, op. cit., s. 175-182:

1. W porównaniu $\mathrm{z}$ „dialogiem sokratycznym" w menippei na ogó wzrasta udział elementów śmiechu.

2. Menippeja całkowicie wyzwala się z tych pamiętnikarsko-historycznych ograniczeń, jakie obowiązywały jeszcze w dialogu sokratycznym. Cechuje ją wyjątkowa swoboda fabularnej i filozoficznej fikcji.

3. Najważniejsza właściwość menippei polega na tym, że krańcowo smiała, wybujała fantastyka czy przygodowośc jest tu umotywowana, usprawiedliwiona i usankcjonowana poprzez cel czysto ideowy, filozoficzny: sytuacje wyjątkowe służą do prowokowania i wypróbowania filozoficznej idei-slowa, prawdy, ucieleśnionej w postaci mędrca.

4. Bardzo ważną właściwość menippei stanowi organiczne zespolenie swobodnej fantastyki, symboliki, a czasem i elementów mistyczno-religijnych, z jednej strony, i krańcowego naturalizmu spelunkowego.

5. Menippeja - to gatunek poruszający „rzeczy ostateczne”. Dąży do wydobycia ostatnich, rozstrzygających słów i zachowań człowieka.

6. Zjawia się w niej konstrukcja trójplanowa: akcję i synkrezy dialogowe przerzuca się z ziemi na Olimp i do piekieł, [...] z równie ostrą precyzją są tu dane „dialogi u progu".

7. W menippei zjawia się szczegolny typ fantastyki eksperymentalnej, [...] jest to opis obserwacji dokonany $\mathrm{z}$ jakiegoś niezwykłego punktu, na przykład $z$ dużej wysokości.

8. Po raz pierwszy pojawia się również to, co nazwać by można eksperymentatorstwem moralno-psychologicznym.

9. Bardzo znamienną cechą menippei są epizody skandalów, ekscentrycznych zachowań, niestosownych wypowiedzi i przemów, czyli wszelkiego rodzaju zakłócenia zwyczajnego, powszechnie przyjętego trybu spraw ludzkich.

10. Menippeja obfituje w kontrasty i oksymorony, [...] lubi igrać gwaltownym zwrotem i odmianą, górą i dołem, wzlotem i upadkiem, nagłym zbliżeniem rzeczy od siebie dalekich, wszelkiego rodzajami mezaliansami.

11. Menippeja wprowadza często elementy u t o p i i społecznej.

12. Menippeje cechuje także szerokie zastosowanie przytoczeń innych gatunków: nowel, listów, wystąpień oratorskich, sympozjow itp., oraz pomieszanie mowy prozatorskiej $\mathrm{z}$ wiązaną.

13. Obecność w menippei gatunków-przytoczeń wzmaga jej wielostylowość i wielotonacyjność; tu bierze początek nowe ujęcie słowa jako materii literatury, znamionujące całą dialogową linię rozwoju prozy literackiej.

14. Ostatnia właściwość: jej publicystyczna wrażliwość na aktualne zdarzenia.

17 H.K. Riikonen, Menippean Satire as a Literary Genre with special reference to Seneca's Apocolocyntosis, "Commentationes Humanorum Litterarum" Helsinki 1987, 83. Obok dopisków rozwijających funkcję „cudzej mowy” i heterogeniczności satyry menippejskiej na szczególną uwagę zasługuje odnotowanie przysłów w Udynieniu Boskiego Klaudiusza: „Seneca also uses proverbs very often. [...] Following Bakhtin, we could say that

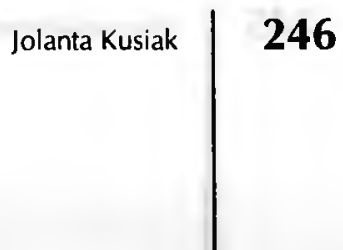


badacz, łącząc wnioski Michała Bachtina i Northropa Frye'a18, za klasyczne satyry menippejskie, poza fragmentarycznie zachowanymi Menipposa i Warrona, uznał: Seneki Apocolocyntosis Divi Claudius, Petroniusza Satiricon libri, Apulejusza Asinus aureus, Boecjusza De consolatione philosophiae, Marcjanusa Kapelli De nuptiis Philologiae et Mercurii ${ }^{19}$. Próbą podsumowania dociekań nad antycznymi satyrami dociekań często sprzecznych ${ }^{20}$ - jest praca Kazimierza Korusa ${ }^{21}$, w której przedstawil teorie Riikonena, wzbogacając je o badania Danuty Shanzer ${ }^{22}$ i własne interpretacje.

Wobec wielu niejasności, jakie unaoczniają się $w$ teoretycznych rozważaniach nad satyrą menippejską, niezwykle potrzebną okazuje się taksonomia, wprowadzona przez Stefana Trappena ${ }^{23}$. Wyraźne oddziele-

the use of proverbs, which represent popular wisdom, is well suited to a genre outside the literary canon, such a Menippean satire", s. 47. Riikonen doliczył się dwunastu lacińskich i jednego greckiego przysłowia w tekście satyry. Włączył satyrę Seneki do tradycji satyr politycznych: „Senecas's Apocolocyntosis is of course a political satire” (s. 42), co poszerza listę Bachtina. Istotne $\mathbf{i}$ fundamentalne dla poetyki menippei jest dostrzeżenie typowej dla niej narracji: pierwszoosobowej w każdym tekście (s. 41).

${ }^{18}$ N. Frye, Anatomy of Critism. Four Essays, Princeton (New Jersey) 1957.

19 H. K. Riikonen, op. cit., s. 9-10. Symposia, mogące zostać sklasyfikowane jako satyry menippejskie, to: Makrobiusza Rozmowy w czasie Saturanliów, Lukiana Dialogi, Juliana Apostaty Biesiada, czyli Święto Kronosa, Atenajosa Sofiści przy uczcie.

20 Por.: J. Styka, op. cit., s. 459 i 454: „Prozometryczne satyry Warrona, pomimo niewątpliwego związku formalnego i ideowego z diatrybami Menipposa, w bardzo poważnym stopniu przynależą do kręgu oryginalnych rzymskich dokonań literackich i stanowią jakby końcowy etap rozwoju italskiej satura, wyznaczonej przez Enniusza, Pakuwiusza i ewentualnych, nieznanych nam autorów archaicznych. [...] Stosując więc przedstawione powyżej główne kryteria gatunkowe satyry menippejskiej (Bachtina, Riikonena i K. Korusa - przyp. J.K), należałoby stwierdzić, iż ujęte w 150 księgach Satyry menippejskie Warrona nie są satyrami menippejskimi".

${ }^{21}$ K. Korus, Wokól teorii satyry menippejskiej, „Eos” 1990, nr 78, s. 119-131.

22 D. Shanzer, A philosophical and Literary Commentary on Martianus Capella's "De nuptiis Philologiae et Mercuri", University of California Publications, Berkeley-Los Angeles-London 1986, „Classical Studies”, vol. 32. W tym monograficznym studium wyróżnione zostały wzorcowe antyczne satyry menippejskie: Warrona Menippea, Lukiana Dialogi, Juliana Apostaty Kronia i tekst zachowany w Papyri Oxyrynchii nr 3010. W wyodrębnionej grupie drugiej "group of prosimetra from late antiquity" obok Marcjanusa Zaślubin Filologii i Merkurego znalazły się Boecjusza O pocieszeniu, jakie daje filozofia i Fulgencjusza Mitologii Księga III.

${ }^{23}$ S. Trappen, op. cit., s. 135-136: „Man begreift die Geschichte der menippeischen Satire am besten, indem man sie in drei Epochen gliedert. Am Anfang steht die Ausbildung der Gatung in der Antike. Da es sich oft genug um greischische Schriffen hendelt, ereignet sich ein bedeutender Teil der frühen Wirkung im Byzantinischen; ein anderer, in seinem Umfang schwer abrenzbarer Teil des Fortlebens der antiken Menippea findet im lateinischen Mittelalter statt. Mit dem Humanismus setzt die zweite Phase der Menippea ein. [...] Der Umfang dieser Literatur ist gross; ihre Rolle für die Geschichte de 16. und 
nie tekstów antycznych, zwieńczonych tradycjami bizantyjskimi i średniowiecznymi prosimetrami od renesansowych i późniejszych, osiemnastowiecznych, pozwala na zauważenie ich odrębnych często poetyk. W badaniach nad menippeą 24 widoczne są dwa nurty: filologiczny, w którym studia nad starożytnymi tekstami mają przynieść odpowiedź na pytanie, co $\mathrm{w}$ istocie konstytuuje osobność gatunkową satyr menippejskich, oraz komparatystyczny, gdzie „satyra menippejska” bywa znakiem, wiążącym odległe tematycznie, czasowo i literacko utwory25.

Posługiwanie się jednym „schematem” gatunkowym wobec np. Satyryków Petroniusza i O pocieszeniu, jakie daje filozofia Boecjusza generuje wiele pułapek. Stąd poza rudymentarnym rozdziałem chronologicznym oraz fluktuującymi cechami satyry menippejskiej wraz z licentia poetica każdego twórcy ważny wydaje się formalny podział na: satyry oraz struktury menippejskie.

Ukierunkowanie satyryczne tekstów uznawanych za wzorcowe satyry menippejskie, poza casusem Boecjusza, nie budzi zastrzeżeń. Jednakowoż - zwłaszcza na gruncie literatury polskiej - przyjęcie struktury menippejskiej jako zewnętrznej jedynie formuły zmienia porządek rodzimej historii gatunku. Za pierwszą polską bowiem satyrę menippejską uznano ostatnio Gadkę Hrycia $z$ Fortunq Jana Szczęsnego Herburta26, napisaną w 1607 roku, wydaną w roku 1612 w Dobromilu. Jacek Sokolski, analizując autobiograficzny ${ }^{27}$ utwór Herburta zestawił go $\mathrm{z}$ wzorcem

17. Jahrhunderts ist bedeutend. [...] Letzlich ist die mächtige Wirkung, die von humanistischen Menippea ausging, die Ursache für die Eigenart der dritten, in ihren Ausläufern bis in unsere Gegenwart hineinreichende Phase".

24 Termin „menippea” bądź „menippeja” odmienny jest od "satyry menippejskiej”. Rozróżnienie owo polega na stosowaniu tegoż pierwszego w szerokim, heterogenicznym, ściślej dialogicznym zasięgu, który obejmuje ów nurt komparatystyczny, jaki wprowadził Michał Bachtin, zaś satyrą menippejską zwie się właściwe, starożytne teksty. Por.: menippea, satyra menippejska, hasła w: Stownik terminów literackich, s. 298 i 498.

${ }^{25}$ Do nich, rozpoczynając od prac Michała Bachtina, należą J. Kristevy, Le mot, la dialogue et le roman, w: taż, Semiotiké. Recherches pour une sémanalyse, Paris 1969, s. 143-173; przekład polski W. Grajewskiego w: Bachtin. Dialog - Język - Literatura, red. E. Czaplejewicz, E. Kasperski, Warszawa 1983, s. 394-417. Niemieckojęzyczne eseje D. Fuchsa, Menippos on the Liffey. Studien zu James Joyce und zur Form der Menippea, München 2005 oraz tenże, Menippos in Dublin, Würzburg 2005 właśnie w tradycję menippei wpisują Ulissesa Jamesa Joyce'a.

26 J. Sokolski, Hryć, Herkules czy Boecjusz? Menippejska satyra Jana Szczęsnego Herburta, w: Muzy i Hestia. Studia dedykowane prof. Ludwice Ślękowej w siedemdziesiatq rocznice urodzin, pod red. M. Cieńskiego i J. Sokolskiego, Wrocław 2000, s. 81-92.

${ }^{27}$ Michała Wiszniewskiego Historia literatury polskiej, t. 7, Kraków 1845, s. 117 podaje: „Herkules Jana Felixa Herburta z Dobromila, pisany przez niego w więzieniu, w którym cały swój żywot i zawód polityczny dziwnie pięknym stylem i nadobną polszczyzną, i wierszem, i prozą opisuje. Żałować tylko przychodzi, iż tę autobiografię (zdaje się tylko 
De consolatione Philosophiae. Podobieństwo wynika z sytuacji ich pisania: powstawały w więzieniu; niektóre sceny, jak wejście in medias res Filozofii autor Gadki Hrycia z Fortunq zaczerpnął od Boecjusza. O pocieszeniu, jakie daje Filozofia napisane jest w prosimetrum, ale elementów komicznych czy satyrycznych raczej w niej brak. Trzeci ${ }^{28}$ polski tłumacz utworu Boecjusza - Tadeusz Jachimowski - objaśniał:

Pierwszy do literatury rzymskiej pismo pocieszające, consolatio, wprowadził $\mathrm{Cy}$ cero. [...] Boecjusz nie sam się pociesza, ale zupełnie słusznie wprowadza obcą osobę, która udziela mu pociechy. Jest to osoba alegoryczna, Filozofia, która $\mathrm{z}$ autorem prowadzi dialog. Co więcej, by ten dialog nie był monotonny zanadto, włącza autor do prozy wiersze, które dialektycznym wywodom pewną przerwę dają i dla czytelnika są pożądanym wytchnieniem*. (* Proza z wierszami - Satura Menippea - forma bardzo lubiana w średniowieczu ${ }^{29}$.

Późnoantyczne prosimetrum i jego staropolskie odbicie, czyli De consolatione Philosophiae i Gadka Hrycia $z$ Fortunq pozostają w formalnej korelacji ze strukturą menippejską, są jednak konsolacjami.

Traktowane jako typowa satyra menippejska Łukasza Opalińskiego Coś nowego, pisanego/ Roku tysiquc sześćsetnego/ Pięćdziesiq̨tego wtórego. / Drukowane w Koziej Gtowie, / Kiedy miesiqc byt na nowie, / Kosztem zaś pana jednego, / z bractwa piławieckiego;/ A drukarniq zaś zakryto,/ Bo by drukarza zabito ${ }^{30}$ wydane anonimowo, również tylko formalnie jej przynależy. Polityczne zaangażowanie autora w sprawę klęski piławieckiej i jej sprawcy podkanclerzego Hieronima Radziejowskiego nie pozwala na jednoznaczne nazwanie tekstu satyrą. Wąska tematyka, zjadliwa krytyka i ostra napaść personalna oraz historyczne uwarunkowanie kwalifikują Coś nowego jako pamflet ${ }^{31}$. Wybija zaś zeń bezpośrednia korespondencja $\mathrm{z}$ francuskim pamfletem politycznym Satire ménippée ${ }^{32}$.

dla przyjaciól, dobrze ówczesnych okoliczności świadomych, pisaną) dziś niełatwo zrozumiećn.

${ }^{28}$ Pierwszym polskim przekładem jest: Skuteczny na wszelkie przygody nieszczęśliwe sposób, wszytkim w utrapieniu zostajqcym podany, to jest Pociecha Filozofiej, niegdy od An. Man. Torq. Seweryna Boecjusza napisana, teraz przez W.X. Jana Alana Bardzińskiego, S. Theologijej Lektora, przeora tęczyckiego Zakonu Kaznodziejskiego, przettumaczona. W Toruniu, nakładem Jana Christiana Laurera, 1694. Starodruk Biblioteki PTPN 4271.

${ }^{29}$ Boecjusz, O pociechach filozofii ksigg pięcioro oraz Traktaty teologiczne, z laciny tłumaczył, dał wstęp i objaśnienia ks. dr T. Jachimowski, Poznań 1926, s. 18.

${ }^{30}$ E. Opaliński, Coś nowego...,w: tegoż, Poeta nowy. Coś nowego, oprac. P. Borek, Kraków 2003, s. 21-64, „Klasyka Mniej Znana”, wyd. według: Ł. Opalinsski, Wybór pism, oprac. i wstęp S. Grzeszczuk, BN I 172, Wrocław 1959.

31 J. Sła wiński, Pamflet, hasło w: Slownik terminów literackich, s. 368: „utwór publicystyczny lub literacki, często anonimowy, mający charakter demaskatorskiej i zwykle 
Wydana anonimowo w 1594 roku w Paryżu ${ }^{33}$ nie odegrała żadnej roli politycznej, była jednak swoistym manifestem, który odpowiadał na zamieszki religijne, jakie wybuchły we Francji po nocy św. Bartłomieja ${ }^{34}$. Ułożona przez sześciu mieszczan ${ }^{35}$ formą przeplotu prozy i poezji oraz tytułem $^{36}$ wskazuje na starożytne inspiracje. Wspólną cechą Satire ménippée i Łukasza Opalińskiego Coś nowego jest zabarwienie polityczne, teksty powstały jako żywa reakcja na konkretne wydarzenia historyczne, ich funkcją wydaje się nie tyle satyryczna demaskacja przywar czy porządku, ile atak na osoby i prawdziwe sytuacje. Odmienność pamfletu od satyry zawiera się również w sile ekspresji, natężenia napięcia, a w obydwu tych tekstach zaś roi się od inwektyw i napastliwych sformułowań. Napisane strukturą menippejską są ostrzejsze od tonacji tylko satyrycznej.

Odmienność starożytnych, renesansowych i późniejszych satyr menippejskich nie wyklucza jednak wspólnych im genologicznych cech. Poza maksymalną otwartością gatunku - jak stwierdził Stefan Trappen: "Die Satire ist insofern gattungslos" 37 - wyraźnym wymogiem staje się satyryczne zabarwienie tekstów.

Problem z kwalifikacją anonimowego utworu Małpa-człowiek w cnotach, obyczajach $i$ kroju (ok. 1710)38 jako stricte satyry menippejskiej

ośmieszającej krytyki znanej osoby, środowiska społecznego czy instytucji. Dla pamfletu znamienne są takie momenty jak ekspresywno-retoryczna stylistyka, skłonność do hiperbolizacji, satyryczne nacechowanie wypowiedzi. Najczęściej kieruje się przeciw istniejącym urządzeniom czy stronnictwom politycznym [...]. Pamflet bywa uprawiany w szczególności w czasach przewrotów społecznych i politycznych (np. w okresie rewolucji francuskiej) oraz polemik ideologicznych i religijnych (np. w okresie reformacji); sprzyjające dla tego gatunku wypowiedzi są warunki wzmożonej dynamiki życia zbiorowego".

${ }^{32}$ Satire ménippée de la vertu du catholicon d'Espagne; et de la tenue des Etats de Paris... A Ratisbonne Chez Mathias Kerner 1664. Starodruk ze zbiorów Biblioteki PTPN 12794 I [na wewnętrznej karcie ołówkiem zapisano: Bruxelles, Fr. Fopper].

33 G. Lanson, P. Tuvfrau, Historia literatury francuskiej $w$ zarysie, przel. W. Bieńkowska, wyd. 3, Warszawa 1971, s. 112-113.

34 Satire menippée przedstawia dwóch kandydatów do francuskiego tronu: księcia Lotaryngii i króla Hiszpanii, wyraźnie wyszydza stronnictwo katolickie, zachwalając „katolikon" lekarstwo dla wyniszczonego wojną kraju. Zob.: A. Armand, Moyen Age XVIe siecles, Paris 1998, s. 361.

$35 \mathrm{O}$ autorach zob.: A. Legarde, L. Michard, XVIe siècle. Les grands auteurs français du programme, t. 2, wyd. 2, Paris 1952, s. 189-190.

36 A także bezpośrednim przywołaniem Metamorfoz albo złotego osła Apulejusza: „Votre Asne qui par aventure, Fut un chef d'ouvre de natura, Plus que l'Asne Apuleien Mais quoi?" - Satire ménippée, s. 304.

${ }^{37} \mathrm{~S}$. Trappen, op. cit., s. 87.

${ }^{38}$ Zob.: T. Witczak, Małpa-cztowiek, hasło w: Dawni pisarze polscy. Od poczqtków piśmiennictwa do Młodej Polski. Przewodnik biograficzny i bibliograficzny, t. 2 (I-Me), koordynacja całości R. Loth, Warszawa 2001, s. 422 oraz Errata do tomów 1-4, w: Dawni pisarze polscy, t. 5 (U-Z). Uzupetnienia, indeksy, Warszawa 2004, s. 737. 
tkwi w niejednorodności gatunkowej menippei, a i nie bez znaczenia jest brak w dawnej literaturze polskiej utworu, który uchodziłby za wzorcowy. Powiązania Małpy-człowieka z twórczością Opalińskiego są bezsprzeczne, gdyż Anonim na nie wskazał: „ma ją z niego na świecie w Satyrze swoim sudanno nader, kształtnie, okrągło i rzetelnie wielki nad zamiar Opaliński"39. Nie wspomniał jednak w tym miejscu Łukasza Opalińskiego, autora Czegoś nowego..., lecz jego brata Krzysztofa, autora zbioru Satyr, wojewodę poznańskiego ${ }^{40}$. Podnoszone zależności genologiczne od pamfletu Coś nowego... w Małpie-cztowieku opierały się na cytowanym fragmencie ${ }^{41}$, choć nie brakowało i głosów wskazujących na powinowactwo z Satyrami Krzysztofa Opalińskiego (1650)42. Układ satyr, ilustrujących przekrój społeczeństwa stanowego ${ }^{43}$, podobieństwa w ostrej krytyce zepsucia obyczajów szlachty ${ }^{44}$, mieszczan ${ }^{45}$, duchowień-

${ }^{39}$ „Małpa-człowiek”. Anonimowa satyra z poczqtku XVIII wieku, wyd. P. Buchwaldówna, Miscellanea staropolskie, „Archiwum Literackie” t. 6, Wrocław 1962, s. 233 (kolejne cytaty z Małpy-czlowieka pochodzą z tegoż jedynego wydania, dlatego oznaczam je tylko numerem strony bądź wersu).

$40 \mathrm{O}$ postaci i twórczości Krzysztofa Opalińskiego zob.: A. Sajkowski, Krzysztof Opaliński. Wojewoda poznański, Poznań 1960.

41 Zob.: T. Kostkiewiczow a, Ignacego Krasickiego wiersze z prozq, „Wiek Oswiecenia” 2002, nr 18, s. 104: „Za pierwszy przejaw zastosowania w naszym piśmiennictwie zabiegu przeplatania prozy i wiersza uznać można powstały ok. $1650 \mathrm{r}$. pamflet polityczny Łukasza Opalińskiego Coś nowego. [...] Z kolei wpływem utworu Opalińskiego thumaczy się zastosowanie prozimetrum w satyrze z czasów saskich Małpa-człowiek, która jednak nie naśladuje postawy i tonu prześmiewczego autora Coś nowego, bliższa jest wywodom moralizatorsko-dydaktycznym, stosującym przemieszanie prozy i wierszy - przytaczanych głównie na zasadzie cytatu - dla urozmaicenia utworu".

42 „Na początku XVIII wieku z czcią wyraża się o Opalińskim autor satyry Matpa-czlowiek" - zob.: L. Eustachiewicz, wstęp do: K. Opaliński, Satyry, Wrocław 2005, s. XLVII.

${ }^{43}$ Wspólne Opalińskiemu i Małpie-człowiekowi jest kompleksowe, przekrojowe sportretowanie w krzywym zwierciadle wszystkich stanów oraz zjadliwa krytyka pijaństwa, zdrad małżeńskich, wojska i przywódców, pozornej pobożności, fałszywych przyjaźni, zbytku i obżarstwa oraz wielu przywar niewieścich.

$44 \mathrm{~K}$. Opaliński, op. cit., Księga I, satyra II Kto jest prawdziwie wolnym szlachcicem, s. 15-24, a fragment opisania Verus eques z Matpy-cztowieka podobne są w: pojęciu, iż o prawdziwym szlachectwie stanowi nie urodzenie, a postępki: „Nie tytuły szlacheckie, ani też/ Urodzenie prawdziwą przynosi nam wolnosć,/ I nie mają tej władzy pozwolić, aby kto/ Czynił co chcial” (ww. 43-45) - „Nie złocistą ostrogą albo szablą i sygnetem herbownym, ale życia cnotliwego splendorem błyskać i szczycić się powinno szlacheckie powołanie. To jest, do przywileju i klejnotu szlachectwa należy nie tylko urodzić się zacnie, ale i żyć takowymże sposobem, cnotliwie i chwalebnie" (191); krytyce pijaństwa (ww. 167-175 i 185) i zajmowania się handlem (ww. $54-55,106-125$ i s. 194) oraz przekupstwa wśród tego stanu (ww. 188-95 i s. 195).

45 Tamże, Księga $V$, satyra $I O$ sposobach pomnożenia miast $i$ na nierzqd $w$ nich, s. 249-262. Przyczyną zepsucia jest powszechne w tym stanie pijaństwo: por. ww. 106-115 i 198-199. 
stwa ${ }^{46}$, chłopstwa ${ }^{47}$, sarkanie na złe wychowanie dzieci i młodzieży ${ }^{48}$ oraz semantyczne nawet cechy ${ }^{49}$ sytuują Matpę-człowieka w bezpośredniej zależności od zbioru Satyr Krzysztofa Opalińskiego, zaś wzorców genologicznych można upatrywać w innych utworach $\mathrm{z}$ epoki.

Paulina Buchwald-Pelcowa wskazała na zbieżności w kompozycji Małpy-człowieka i Worka Judaszowego Sebastiana Fabiana Klonowica ${ }^{50}$, zas jej ostrożna kwalifikacja ${ }^{51}$ Małpy-człowieka jako satyry menippejskiej osłabiona jest przez pewną „traktatowość 52 tekstu, która według badaczki w swym dydaktyzmie i moralizatorstwie nie może łączyć się z satyrycznością:

Malpa-czlowiek została zbudowana raczej jako traktat moralizatorsko-satyryczny, prozaiczny $z$ wstawkami wierszowanymi, a więc zbliżony do satyry menippejskiej. [...] W efekcie powstało dzieło, $w$ którym dwie tendencje - satyryczna i moralizatorsko-satyryczna - nie zawsze współgrały ze sobą, w ostatecznym wyniku dominująca była tendencja satyryczna $[\ldots]^{53}$.

46 Tamże, Księga IV, satyra X Na obyczaje duchownych, s. 234-248 oraz fragment Małpy-cztowieka, s. 222-233 są podobnie obawami ekskomuniki ww. 1-6 i s. 222, po czym następują tożsame krytyki nieczystości, pijaństwa, niedouczenia, chciwości i obłudy.

47 Tamże, Księga I, satyra III Na ciężary $i$ progressyjq chlopskq $w$ Polscze, s. 24-30 i 207-210. Znamienne, iż u obu satyryków w miejscu krytyki chłopstwa pojawiają się passusy poświęcone czarownicom: ww. 63-70 oraz s. 208-209.

48 Tamże, Księga I, satyra I Na złe ćwiczenie i rozpasanq edukacyję młodzi, s. 7-14 oraz Księga II, satyra V Na ojców, którzy złym przykladem synów psujq, s. 102-112 zbieżne są z krytyką psucia złym przykładem przez dorosłych (s. 211-213), złą edukacją (s. 214).

49 Zarówno Opaliński, jak i Anonim lubują się w dosadnych wyzwiskach, pojawia się więc częstokroć „gnojek"; wyimaginowanymi rozmówcami w Satyrach są Mikołaj i Stanisław, postaci te są rozmówcami i w Małpie-człowieku s. 237-246; w krytyce fałszywej pobożności posłużyli się określeniem „liżyobrazki” (Księga II, satyra II Na liżyobrazków...).

50 P. Buchwald-Pelcowa, Satyra czasów saskich, „Studia Staropolskie”, t. 25, Wrocław 1969, s. 119.

51 Kwalifikacja to niejednoznaczna, gdyż wprowadzony termin "lament satyryczny” odnosi się i do Malpy-człowieka, por.: "«Łami by pisać potrzeba», gdyż «żal i wstyd wlasny wydzierają piórom - stwierdzal na początku XVIII wieku anonimowy twórca Matpy-czlowieka. Ton użalania się nad ruiną ojczyzny, obawa przed grożącą jej zgubą doszła do głosu najsilniej w lamentach, a wśród nich i w lamentach o pewnym zabarwieniu satyrycznym" - tamze, s. 143.

52 Traktatami z epoki, które postulowały reformy i określały kierunki zmian, odnoszącymi się do politycznych realiów, ale i nie bez wzmianek o obyczajowych byly memoriały „hrabiego Laganski (1714) Sentimens (!) du Comte de Lagnasc..., J.H. Flemminga (ok. 1701?) Jak tron polski dziedzicznym uczynić $i$ prawdziwq wolność $w$ tym kraju zaprowadzić" czy samego Augusta II Sasa Jak Polskę przemienić w kraj kwitnqcy - cyt. za: J. Staszewski, „Jak Polskę przemienić $w$ kraj kwitnqcy...” Szkice i studia $z$ czasów saskich, Olsztyn 1997.

53 P. Buchwald-Pelcowa, op. cit., s. 120. 
Forma prosimetrum Małpy-człowieka, gdzie dwadzieścia poetyckich struktur wplecionych jest $\mathrm{w}$ tok zmonologizowanego wywodu, wskazuje jednoznacznie na strukturę menippejską. Przydaje jej charakteru również wprowadzenie dialogów jako odrębnych gatunkowo scen, co spełnia postulat czy cechę „maksymalnej otwartości gatunkowej”, którą „klasyczna" menippea wykazuje. Tonacja satyryczna, gdzie dydaktyzm i zacięcie moralizatorskie są niejako jej przyczynami, uwydatniona została komizmem sytuacyjnym, językowym oraz intencją prześmiewczą utworu. Do cech wspomagających tezę o kwalifikacji Małpy-człowieka jako satyry menippejskiej dołączyć można - paradoksalnie - i cechę, która, według Buchwald-Pelcowej, stanowi o jej "traktatowości”, czyli wprowadzenie w ciąg tekstu łacińskiego zbioru praw rycerskich i precyzyjną budowę $\mathrm{z}$ wyodrębnionymi tematycznie partiami. Według zasady 0 „wchłanianiu” przez menippeę różnych gatunków i traktat nie wyklucza uznania utworu za satyrę menippejską. Otwartość genologiczna, komiczne i satyryczne odwrócenie porządku według paraleli małpa-człowiek, reportażowa spostrzegawczość jako żywa reakcja na współczesne wydarzenia (tu: stan moralności) oraz poszczególne właściwości stylowe wskazują na zasadność uznania Matpy-człowieka za satyrę menippejską.

Do jej wcześniejszych polskich odmian zaliczyć można trzy, wydane anonimowo bez miejsca i daty, pisane przeplotem prozy i wiersza satyry54: Żonę wyćwiczonq ${ }^{55}$, Złote jarzmo małżeńskie ${ }^{56}$ oraz Gorzkq wolność młodzieńskq albo odpowiedź na złote jarzmo małżeńskie ${ }^{57}$. Wspólna im jest struktura przeplotu poezji i prozy, także łacińskich partii z polskimi. Ironia i przewrotność $w$ zachwalaniu małżeństwa jest dominującą cechą kompozycji Złotego jarzma małzeńskiego, gdzie autor zapowiada:

54 Żona wyćwiczona autorstwa prawdopodobnie Jana Karola Dachnowskiego jest przeróbką czy też nową redakcją Ztotego jarzma matżeńskiego. Odpowiedzią na Ztote jarzmo jest Gorzka wolność mlodzieńska pióra prawdopodobnie Andrzeja Żydowskiego. Zob.: Bibliografia literatury polskiej "Nowy Korbut", t. 3: Piśmiennictwo staropolskie, oprac. Zespół pod kierownictwem R. Pollaka, Warszawa 1965, hasła: Dachnowski Jan Karol, Ztote jarzmo matżeńskie, Żydowski Andrzej.

65 Żona wyćwiczona, b.m.r.w., pol. XVII w., domniemany autor Abraham Prowana. Starodruk ze zbiorów Biblioteki PAN w Kórniku, sygn. 13170. O satyrze zob.: J. Party$\mathrm{ka}$, „Żona wyćwiczona”. Kobieta pisząca $w$ kulturze XVI i XVII wieku, Warszawa 2004, s. 12-13, „Seria Rozprawy Literackie IBL”, t. 82, red. A. Okopień-Sławińska, J. Abramowska, A. Kowalczykowa, G. Wołowiec, M. Głowiński, red. naukowa J. Abramowska.

${ }_{66}$ Ztote jarzmo malżeńskie, b.m.r.w., domniemany autor Abraham Prowana. Starodruk ze zbiorów Biblioteki PAN w Kórniku, sygn. 13169, Mf 6599.

${ }^{67}$ Gorzka wolność mtodzieńska albo odpowiedź na ztote jarzmo malżeńskie przez jednq damę dworskq, b.m.r.w., domniemany autor Andrzej Żydowski. Starodruk ze zbiorow Biblioteki PAN w Kórniku, Mf 6599. 
Dlatego autor bezżeństwa chwali,

Święte małżeństwo niech trwa w swej powadze,

Tylko brakować je główkami radzę.

Iż każda przymiot ma swój białogłowa,

W żołądku byś uwarzył, surowa.

Trudno z wszytkiemi o konia przymioty,

I o niewiastę tak przybraną w cnoty:

Żeby nie było co w której naganić,

Trzeba jej szukać gdzie $\mathrm{z}$ dalekich granic ${ }^{58}$.

Ostra i zjadliwa krytyka stanu niewieściego właściwa jest zwłaszcza Gorzkiej wolności mtodzieńskiej, również przewrotnie skonstruowanej wokół rzekomej jego pochwały. Uderzają obydwie pasją satyryczną, godzącą w przywary typowe kobietom, choć np. to tylko im zarzuca się pijaństwo. Żona wyćwiczona zaś wyraża obawy przed niewiastami wykształconymi, które przejmują zdominowaną przez mężczyzn sztukę pisania i czytania.

Ow ton lamentacyjny $w$ staropolskich satyrach, zaobserwowany przez Buchwald-Pelcową, który pozwolił wyodrębnić je nieomal gatunkowo, zauważalny jest i w Złotym jarzmie małżeńskim:

Dyskurs, który piszę, pewnie cię czytając rozśmieszy: ale wiedz, że ja pisałem go ledwie nie płacząc, który nie tak cię rozśmieszy, jak twoje ożenienie ${ }^{59}$.

I nawet w motywie „pisania łzami” Małpa-człowiek pozostaje zbieżna z wcześniejszymi satyrami menippejskimi. Połączenie satyrycznej wymowy i koncepcji utworów z formą przeplotu poezji i prozy pozwala wskazać na kwalifikację gatunkową jako menippeę. Małpa-człowiek bezsprzecznie odpowiada wymogom "otwartości" genologicznej i pozostałym konstytutywnym cechom, do jakich zaliczyć wypada: satyryczność, prosimetrum, komizm, żywą reakcję na współczesne zdarzenia i swoisty dydaktyzm. Nie jest efemerydą gatunkową na gruncie literatury polskiej: wieńczy staropolskie struktury i satyry menippejskie.

Pokłosiem struktury menippejskiej był list menippejski, rozwinięty jako osobna latorośl prosimetrum. Z ustaleń Teresy Kostkiewiczowej wynika, iż „inny typ prozimetrum pojawil się we Francji około połowy XVII wieku"60. Wydane w 1714 roku listy Chapelle'a byly wariantem

58 Ztote jarzmo matżeńskie, Mf 6599, A2.

59 Tamże, A3.

${ }^{60}$ T. Kostkiewiczowa, op. cit., s. 102-103: „Jednym z jego twórców był Jean François Sarasin, poeta o dobrym wyksztalceniu humanistycznym i znajomości antyku, bywalec paryskich salonów, który do spotykanych tam kobiet adresowal eleganckie listy prozą i wierszem, nacechowane kokieterią, ale też dowcipem i łagodną ironią. [...] W utworach Sarasina dominująca dotychczas w prozimetrum kategoria satyryczności została 
struktury menippejskiej, jakim stała się forma listu menippejskiego. Podobnym polskim przykładem jest fragment Dyskursu o szczęśliwości życia wiejskiego (1744) Krzysztofa Udalryka Radziwiłła61, będący częścią listu menippejskiego do brata. Ta „epistoła o menippeicznym charakterze" utrzymana $\mathrm{w}$ tonie zwierzeń, zasadza się na „pochwale życia ziemiańskiego"62 i jest jednym z niewielu przyczynków do historii menippei, a bodaj i pierwszym listem menippejskim w polskiej literaturze. Z listów menippejskich wyodrębniły się treściowo w osobną kategorię listy z podróży, „pisane przez mniej znane postacie, ale także twórców pierwszoplanowych: Jeana Racine'a, La Fontaine'a [...] wreszcie Woltera"63. W tę tradycję wpisuje się Opisanie podróży $z$ Warszawy do Biłgoraja Ignacego Krasickiego (1782). Wiersze z prozą Księcia Biskupa Warmińskiego stanowią najliczniejszy zbiór polskich listów menippejskich, zróżnicowanych formalnie i treściowo ${ }^{64}$.

W epistołach menippejskich zachował się ślad tradycji mieszania prozy i poezji, są one tylko wariantem struktury menippejskiej. Wyrastają jednak genologicznie $\mathrm{z}$ jednego pnia, jakim jest twórczość Menipposa z Gadary, która zainicjowala przebogatą tradycję tekstów menippeicznych, dzielonych na satyry, struktury, listy czy rozmowy zmarlych.

przytłumiona, a na plan pierwszy wysunęła się listowość, wyznaczająca sytuację komunikacyjną utworu i jego konstrukcję. List był punktem odniesienia drugiego z bliżej znanych poetów francuskich, piszących wiersze z prozą - Claude'a Emanuela Lhuilliera, zwanego Chapelle. Utwory jego, adresowane do konkretnych, znanych osób, były utrzymane w tonie osobistym, a zarazem poważnym i refleksyjnym".

61 E. Aleksandrowicz, Krzysztof Udalryk Radziwitl, hasło w: Dawni pisarze polscy..., t. 3, Warszawa 2003, s. 336a-337b.

62 Zob.: B. Judkowiak, „Choć umre za literata...”. Przyczynki do sylwetki literackiej księcia Udalryka Radziwitla (1712-1770), w: Dwór majqcy w sobie osoby $i$ mózgi rozmaite. Studia $z$ dziejów literatury i kultury. Ksiqżka poświęcona prof. Alojzemu Sajkowskiemu $w$ siedemdziesiqtq̨ rocznicę urodzin, pod red. B. Sienkiewicz i B. Judkowiak, Poznań 1991, s. 71-72.

63 T. Kostkiewiczowa, op. cit., s. 103.

64 Zob.: R. Krzywy, List - relacja podróżnicza - satyra menippejska. Ksztalt gatunkowy „Podróży $z$ Warszawy do Biłgoraja” Ignacego Krasickiego, w: Wokót reportażu podróżniczego, red. E. Malinowska, D. Rott przy współudziale L. Budzyńskiej-Daca, Katowice 2004, s. 54-67. 